Marquette University

e-Publications@Marquette

Psychology Faculty Research and Publications

Psychology, Department of

$4-1-2010$

\title{
Adolescent Triangulation into Parental Conflicts: Longitudinal Implications for Appraisals and Adolescent-Parent Relations
}

Gregory M. Fosco

University of Oregon

John H. Grych

Marquette University, john.grych@marquette.edu

This is the accepted, peer-reviewed, corrected version before publisher formatting.

Journal of Marriage and Family, Volume 72, No. 2 (April 2010), DOI: 10.1111/

j.1741-3737.2010.00697.x.

The definitive version is available at www.blackwell-synergy.com. 
NOT THE PUBLISHED VERSION; this is the author's final, peer-reviewed manuscript. The published version may be accessed by following the link in the citation at the bottom of the page.

\title{
Adolescent Triangulation into Parental Conflicts: Longitudinal Implications for Appraisals and Adolescent-Parent Relations
}

\author{
Gregory M. Fosco \\ Child and Family Center, University of Oregon \\ Eugene, OR \\ John H. Grych \\ Department of Psychology, Marquette University \\ Milwaukee, WI
}

\begin{abstract}
Although triangulation into parental conflict is a risk factor for child and adolescent maladjustment, little is known about how triangulation affects adolescents' functioning or the factors that lead children to be drawn into parental disagreements. This prospective study examined the relations between triangulation, appraisals of conflict, and parent-child relations in a sample of 171 adolescents, ages 14 to 19 years, at 2 time points. Crosslagged path analyses revealed that youths who experienced greater threat in response to conflict reported increases in triangulation over time, and triangulation was associated with increased self-blame and diminished parentadolescent relations. This study highlights links between intrapersonal, dyadic, and triadic processes and suggests a mechanism by which interparental discord spills over into parent-adolescent relations.
\end{abstract}


Keywords: cognition; fathers; interparental conflict; longitudinal method; mothers; parent-adolescent relations

Family systems theory offers a framework for investigating how broader patterns of family interaction influence the effects of interparental conflict on children (Davies, Harold, Goeke-Morey, \& Cummings, 2002; El-Sheikh \& Elmore-Staton, 2004; Grych, Raynor, \& Fosco, 2004). The process of triangulation in particular has been highlighted by family theorists and researchers (Buchanan \& Waizenhofer, 2001; Buehler, Lange, \& Franck, 2007; Grych et al., 2004) because chronic, unresolved interparental discord can strain the coparental relationship and lead to children being drawn into parental conflict in an effort to resolve it or diffuse the resulting tension (Minuchin, 1974). Triangulation has been found to mediate the association between interparental conflict and child adjustment problems (Buehler et al.; Fosco \& Grych, 2008), but little is known about the factors that predict when children will be triangulated or how being drawn into parental conflict leads to maladjustment.

Explicating the links between intrapersonal, dyadic, and triadic factors associated with child adjustment is an important step toward building more comprehensive models that explain how witnessing parental discord affects youths' development. Therefore, the goal of the present study was to investigate relations between triangulation into parental disagreements and two processes shown to be pathways through which interparental conflict affects youths' functioning: adolescents' appraisals of conflict and the quality of parent-child relationships. We measured triangulation as adolescent's subjective sense of feeling drawn into or caught in the middle of parental discord and utilized a short-term longitudinal design to investigate the associations between triangulation and two sets of mediators related to adolescent outcomes: (a) appraisals of threat, self-blame, and coping efficacy and (b) conflict and closeness in youths' relationship with each parent. Next, we provide the conceptual rationale for expecting triangulation to be associated with conflict appraisals and parent-adolescent relationships. 


\section{Triangulation and Adolescents' Appraisals of Interparental Conflict}

According to the cognitive-contextual framework (Grych \& Fincham, 1990), children exposed to interparental conflict attempt to understand how the discord will affect them (threat), what they can do about the conflict (coping), and who is responsible for it (blame). Their appraisals are proposed to mediate the impact of conflict on their adjustment, and a recent meta-analysis confirmed that threat, coping, and blame appraisals consistently are linked with internalizing and externalizing problems (Rhoades, 2008). Children's conflict appraisals also are shaped by contextual factors that include broader patterns of interaction in the family. Being triangulated into parental disagreements is likely to make the conflict more threatening to children because they may become the target of parental hostility or aggression or feel torn between their loyalties toward each parent. In a study of 6- to 10-year-old children, Kerig (1995) found that children in families characterized by cross-generational coalitions were more threatened by parental conflict than those with other family dynamics. More recently, Gerard, Buehler, Franck, and Anderson (2005) reported that 10- to 14-year-old children who were drawn into marital conflict reported higher levels of threat and lower coping efficacy when disagreements arose.

Triangulation also may elicit greater self-blame because children are more likely to feel responsible for causing or helping to resolve the conflict. Self-blame is more common when the topic of a disagreement is child related (Grych \& Fincham, 1993), which may suggest that children could be more likely to assume responsibility for conflicts that involve them in some way. Using structural equation modeling, Gerard and colleagues (2005) found that parent-reported triangulation was indirectly associated with self-blame through relations with threat and coping.

Although these studies show that triangulation is correlated with children's appraisals, the data are cross-sectional and so do not address the question of whether appraisals shape or are shaped by being drawn into parental disagreements. It is plausible that children's appraisals of parental conflict may lead them to intervene in the

Journal of Marriage and the Family, Vol 72, No. 2 (Summer 2010): pg. 254-266. DOI. This article is (c) Wiley and permission has been granted for this version to appear in e-Publications@Marquette. Wiley does not grant permission for this article to be further copied/distributed or hosted elsewhere without the express permission from Wiley. 
interaction. Grych and Fincham (1993) found that children listening to standardized parental conflict vignettes were more likely to endorse intervening in the conflict when the topic of the disagreements was child related. Children who perceive conflict as threatening to their emotional security may withdraw or try to stop the conflict in order to regulate their exposure to the threat (Davies \& Cummings, 1994; Schermerhorn, Cummings, DeCarlo, \& Davies, 2007). Similarly, adolescents who are triangulated into parental conflicts may feel less able to cope (Gerard et al., 2005). Thus, it is possible that threat has unique associations with adolescent involvement in conflict and with coping efficacy. Taken together, these studies highlight the possibility that relations between triangulation and appraisals may be bidirectional.

\section{Triangulation and Parent-Adolescent Relationships}

The association between interparental conflict and diminished parenting is well established (Buehler \& Gerard, 2001; Erel \& Burman, 1995; Krishnakumar \& Buehler, 2000), but the mechanisms that drive the diffusion of negativity from interparental to parent-child subsystems are less clear. Triangulation represents a violation of the boundary between interparental and parent-child subsystems and consequently could affect children's relationships with their parents (Kerig, 2005). Being caught in the middle of a parental disagreement places youths in a difficult position in which they may feel pressure to choose between their parents. Choosing to side with one parent may harm their relationship with the other, may lead to resentment of their parent ally, and may instigate conflict between adolescents and their parents. In addition, repeated involvement in parental discord may facilitate aggression in adolescents through maladaptive coping (Fosco \& Grych, 2008) or by socializing aggressive responding to parental conflicts over time (Davis, Hops, Albert, \& Sheeber, 1998).

One study examining adolescent-parent relations by parent and child gender reported that triangulated adolescent girls tended to view their mothers and fathers as less emotionally available, but the study did not find similar relations for boys (Bosco, Renk, Dinger, Epstein, \& Phares, 2003). Similarly, Peris, Goeke-Morey, Cummings, and Emery

Journal of Marriage and the Family, Vol 72, No. 2 (Summer 2010): pg. 254-266. DOI. This article is (c) Wiley and permission has been granted for this version to appear in e-Publications@Marquette. Wiley does not grant permission for this article to be further copied/distributed or hosted elsewhere without the express permission from Wiley. 
(2008) found that parentification, a process through which parents rely on their children for emotional support, was linked with perceptions of lower parental warmth and responsiveness. To our knowledge, only one study has directly assessed youths' involvement in interparental conflicts and parent-youth conflict. In a cross-sectional sample of 641 12- to 18-year-old youths, covert interparental conflict (defined as youth participation in interparental conflicts) was associated with greater parent-youth conflict (Bradford, Vaughn, \& Barber, 2008). Each of these studies was cross-sectional, and consequently it is impossible to evaluate the direction of effects.

The quality of parent-adolescent relationships also may shape adolescents' experiences of triangulation. In the context of secure adolescent-parent relationships, conflict may be less distressing (Davies et al., 2002; Grych et al., 2004), and consequently children may be less likely to enter into parental disagreements or to feel caught in the middle when conflicts do occur (Buchanan, Maccoby, \& Dornbusch, 1991). It also is possible that parent-adolescent conflict may cause interparental conflict (Erel \& Burman, 1995). When parents argue about adolescent-related topics, adolescents may feel greater responsibility for causing the argument (Grych \& Fincham, 1993) or motivated to provide input in the outcome of the conflict.

\section{The Current Study}

Although they are limited, existing data support the possibility that triangulation may affect children's adjustment by influencing their conflict appraisals and relationships with their parents. Because the associations among triangulation, appraisals, and parent-child relations may be bidirectional, cross-sectional studies tell us little about the role of triangulation in understanding the link between interparental conflict and child adjustment. To help untangle these temporal relations, we utilized cross-lagged analyses to examine the relations between triangulation and each of the other mediators at two points in time, 6 months apart. This analytic approach enabled us to determine whether adolescents' appraisals and quality of relationships with their parents at Time 1 ( $\mathrm{T} 1$ ) predicted the degree to which they felt caught in the middle of parental disagreements at Time 2 (T2) or whether experiences with triangulation predicted later appraisals and

Journal of Marriage and the Family, Vol 72, No. 2 (Summer 2010): pg. 254-266. DOI. This article is @ Wiley and permission has been granted for this version to appear in e-Publications@Marquette. Wiley does not grant permission for this article to be further copied/distributed or hosted elsewhere without the express permission from Wiley. 
parent-child relationships. Consistent with family systems theory, chronic interparental discord was expected to be linked with increased triangulation over time. In turn, triangulation was expected to be linked with (a) greater threat and self-blame and reduced coping efficacy at T2 and (b) increased parent-adolescent conflict and diminished parent-adolescent closeness at T2. We also explored whether parent or child gender influenced the nature of these associations. Research examining the role of parent and child gender in relation to the variables of interest in this study has been inconsistent, but some evidence suggests that the link between parental conflict, youth involvement in conflict, and parent-child relationships may be stronger for girls than for boys (Bosco et al., 2003; Kerig, 2005; Shelton, Harold, Goeke-Morey, \& Cummings, 2006).

Adolescents were the focus of this study for several reasons. First, adolescents may be more likely to become involved in parental disagreements because they have a more sophisticated understanding of the dynamics of interpersonal conflict and a greater repertoire of potentially helpful ways to resolve conflict than younger children. In the only study directly testing this idea, Davies and Forman (2002) found that 10- to 15-year-old youths were more likely to state that they would intervene in a parental disagreement than were 6- to 9year-old children. Second, adolescence may be a particularly problematic time for triangulation to occur. Triangulation may lead to increased threat or self-blame, which are developmentally less common, and may be particularly problematic in older children (Jouriles, Spiller, Stephens, McDonald, \& Swank, 2000). Also, adolescence is a period when youths normatively seek greater autonomy from their parents and spend more time with their peers, and becoming involved in parental discord may interfere with these developmental tasks by increasing their concerns about and time with their parents. Further, triangulation may disrupt positive parentadolescent relations that promote an adaptive transition to adulthood (Crawford \& Novak, 2008).

Journal of Marriage and the Family, Vol 72, No. 2 (Summer 2010): pg. 254-266. DOI. This article is (c) Wiley and permission has been granted for this version to appear in e-Publications@Marquette. Wiley does not grant permission for this article to be further copied/distributed or hosted elsewhere without the express permission from Wiley. 
NOT THE PUBLISHED VERSION; this is the author's final, peer-reviewed manuscript. The published version may be accessed by following the link in the citation at the bottom of the page.

\section{Method}

\section{Participants and Procedures}

Participants were recruited from a large, ethnically diverse public high school in an urban area (see Grych et al., 2004). Letters explaining the study and consent forms were sent home to parents of students who were enrolled in social studies classes at the school and $80 \%$ of parents gave permission for youth participation. Youths who obtained parents' informed consent were invited to participate, and approximately $75 \%$ of those students were present on the day of the collection and agreed to complete the survey packet. Data collections took place during 90-min social studies class periods, with two researchers and the teacher present to answer any questions individually. Those who had not obtained parental consent were excused and given an alternate activity to complete in a different location. Adolescents' signed consent was then obtained, and questionnaires were distributed with the instructions to complete them quietly without conversing with their peers. A total of 326 9th- through 12 th-grade students (60.4\% girls) who ranged in age from 14 to 19 years $(M=16.31, S D=1.17)$ completed the questionnaires at the first data collection (T1). In this sample, $52.5 \%(n=171)$ of the adolescents reported their parents were married, and $46.0 \%$ reported their parents were divorced $(n=150)$. No students were excluded from participation so as to maximize generalizability of the study. Participants were instructed to respond to questionnaires about interparental conflict or parent-child relationships in a manner that best captured their family circumstances. The ethnic makeup of the sample was 56.7\% Caucasian, 12.3\% African American, 19.6\% Latino/Hispanic, 4.3\% Asian/Pacific Islander, 1.8\% Native American, $2.1 \%$ Biracial, and $3.1 \%$ other. No socioeconomic status information was collected from the participants.

The second data collection (T2) occurred approximately 6 months later. At that time, students were enrolled in different classes than at $\mathrm{T} 1$, which made it impossible to distribute the questionnaire packets to the same groups that had completed them at Time 1. Instead, all Time 1 participants were excused from their third-period class and invited to fill out the packets in the lunchroom at the same

Journal of Marriage and the Family, Vol 72, No. 2 (Summer 2010): pg. 254-266. DOI. This article is (c) Wiley and permission has been granted for this version to appear in e-Publications@Marquette. Wiley does not grant permission for this article to be further copied/distributed or hosted elsewhere without the express permission from Wiley. 
time. Many T1 participants either were absent from school that day, failed to receive the message to go to the lunchroom, or failed to make it to the lunchroom after leaving their class. As a result, 171 students, $52.5 \%$ of the original sample, completed the T2 assessment. To determine if the T2 sample was representative of the larger T1 sample, we computed a series of $t$ tests and chi-square tests on demographic variables and variables of substantive interest in the study. Comparisons of adolescents who did and did not participate at T2 yielded no significant differences for gender, ethnicity, or substantive constructs of interest: interparental conflict, triangulation, appraisals, parent-child relationships, or parent-child conflict. Two differences emerged for control variables. Youths who did not participate were slightly older than those who did, $t(322)=3.38, p$ $<.01$, and more likely to come from divorced households, $t(319)=$ 2.26, $p<.05$.

\section{Measures}

\section{Interparental conflict.}

Participants' reports of their parents' conflicts were assessed using the Conflict Properties subscale of the Children's Perception of Interparental Conflict questionnaire (CPIC; Grych, Seid, \& Fincham, 1992). The 19-item Conflict Properties scale assesses the frequency, intensity, and resolution of interparental conflict. Sample statements include "I often see or hear my parents arguing" and "My parents get really mad when they argue" to which children respond on a 3-point scale (True, Sort of true, or False). This measure correlates significantly with parental reports of interparental conflict and has demonstrated satisfactory levels of internal consistency and test-retest reliability (see Grych et al., 1992). The reliability of the Conflict Properties subscale in the present sample (as: $\mathrm{T} 1=.94, \mathrm{~T} 2=.93$ ) was consistent with values reported by Grych and his colleagues (1992) for children and by Bickham and Fiese (1997) for adolescents.

\section{Triangulation.}

Adolescent triangulation into parental conflicts was assessed using the Triangulation subscale of the CPIC (Grych et al., 1992). This

Journal of Marriage and the Family, Vol 72, No. 2 (Summer 2010): pg. 254-266. DOI. This article is (C Wiley and permission has been granted for this version to appear in e-Publications@Marquette. Wiley does not grant permission for this article to be further copied/distributed or hosted elsewhere without the express permission from Wiley. 
eight-item subscale assesses a wide range of triangulation behaviors, capturing the extent to which adolescents feel involved in, caught in the middle of, or drawn into cross-generational coalitions during their parents ' conflict. Sample items include "When my parents argue I end up getting involved somehow" and "I feel caught in the middle when my parents argue." This scale correlates with observed child involvement in interparental conflict during triadic family interactions (Lindahl, 1998). Reliability of the Triangulation subscale in this sample was .72 at T1 and .80 at T2.

\section{Appraisals of interparental conflict.}

The Perceived Threat, Coping Efficacy, and Self-Blame subscales from the CPIC (Grych et al., 1992) were used to assess adolescents' appraisals of interparental conflict. Children endorsed items as True, Sort of true, or False for all three scales. The six-item Perceived Threat subscale assesses the level of threat felt by respondents when interparental conflict occurs. Sample items include "I get scared when my parents argue" and "When my parents argue, I'm afraid something bad will happen." The Coping Efficacy subscale consists of six items and measures adolescents' beliefs that they are able to respond effectively to parental arguments when they occur. Sample items include "When my parents argue I can do something to make myself feel better" and "When my parents argue there's nothing I can do to stop them." The nine-item Self-Blame scale taps the extent to which parental disagreements concern child-related issues as well as the respondents' tendency to blame themselves for these disagreements. Sample items include "It is usually my fault when my parents argue" and "My parents blame me when they have arguments." The validity of these scales as measures of children's subjective evaluations of conflict was supported by significant correlations with children's appraisals of specific episodes of conflict (see Grych et al., 1992). Across all CPIC items, response options alpha coefficients for these scales in the present sample were adequate for Threat (as: T1 $=.81$, $\mathrm{T} 2=.84$ ) and Self-Blame ( $a \mathrm{~s}: \mathrm{T} 1=.85, \mathrm{~T} 2=.85)$. The Coping Efficacy subscale had notably lower internal consistency at both time points (as: $\mathrm{T} 1=.56, \mathrm{~T} 2=.49$ ), indicating greater error variance in the scale, which may reduce the probability of finding a statistically significant relationship with other variables.

Journal of Marriage and the Family, Vol 72, No. 2 (Summer 2010): pg. 254-266. DOI. This article is (c) Wiley and permission has been granted for this version to appear in e-Publications@Marquette. Wiley does not grant permission for this article to be further copied/distributed or hosted elsewhere without the express permission from Wiley. 


\section{Adolescent-parent conflict.}

Finally, adolescents completed the Conflict Tactics Scale, ParentChild version (CTS-PC; Straus, 1979). Adolescents rated the frequency of conflict behaviors that occurred with their mothers and fathers separately over the past year on a scale ranging from 0 (never) to 6 (more than 20 times). The 12 items on this scale ranged from lower levels of parent-adolescent conflict (e.g., "raised voice and yelled at you") to more intense levels of conflict (e.g., "pushed, grabbed or shoved you"). This measure was reliable for mother-adolescent (as $=.92, .85)$ and father-adolescent $(a \mathrm{~s}=.90, .85)$ conflict at T1 and T2, respectively.

\section{Adolescent-parent closeness.}

Adolescents completed the trust and communication scales of the Inventory of Parent and Peer Relationships (IPPA; Armsden \& Greenberg, 1987). These subscales were highly correlated ( $r s=.82-$ -.87 , ps $<.001$ ) and thus were combined to create a single scale measuring the quality of adolescents' relationships with their mothers and fathers, labeled "closeness." This scale consists of 20 items, rated on a 5-point Likert scale ranging from almost never or never to almost always or always and included items such as "My father encourages me to talk about my difficulties" and "I tell my mother about my problems and troubles." Closeness scales demonstrated good internal consistency for mothers and fathers at T1 and T2 (as $=.95)$.

\section{Results}

Analyses for the current study were conducted in two parts, first examining relations between triangulation and adolescent appraisals and then links between triangulation and parent-adolescent relationships. The analytic plan was the same for both parts. First, correlations among variables were examined to establish links between T1 and T2 variables. Then, using Amos 16.0 (Arbuckle, 2007), gender group comparisons were conducted to determine if models were consistent for boys and girls. Finally, on the basis of those findings, models were computed using a full information maximum likelihood (FIML) method to utilize all available data at both time points and 
minimize bias in the estimates (Widaman, 2006). As models were computed, covariances between residuals at each time point were included to help reduce monomethod bias and evaluate whether longitudinal associations were significant after accounting for these associations. Adolescent age and gender and a dichotomous indicator of divorce (whether or not parents were divorced) were included in models by including paths to variables for which there were significant bivariate correlations. Full path models were first evaluated for overall model fit, with preference given to models with nonsignificant $X^{2}$ values, Comparative Fit Index (CFI) values greater than .90, TuckerLewis Index (TLI) values greater than .90, and Root Mean Square Error of Approximation (RMSEA) values below .08. Because of the large number of parameters in the model and the moderate sample size, nonsignificant paths $(p>.10)$ were trimmed to compute final models. Then, standardized path coefficients were examined to determine the nature of relationships among variables.

\section{Triangulation and Appraisals of Interparental Conflict}

The first set of analyses focused on the relations between interparental conflict, triangulation, and adolescent appraisals of threat, coping efficacy, and self-blame. Table 1 presents means, standard deviations, and correlations. Interparental conflict was related to higher levels of adolescents' triangulation, threat, and blame and lower levels of coping efficacy. Constructs were stable between T1 and T2, with correlations ranging from .60 to .79. Finally, conflict at T1 was correlated with threat and blame at $\mathrm{T} 2$ and triangulation at $\mathrm{T} 1$ was correlated with $\mathrm{T} 2$ threat, coping, and blame.

Journal of Marriage and the Family, Vol 72, No. 2 (Summer 2010): pg. 254-266. DOI. This article is (C Wiley and permission has been granted for this version to appear in e-Publications@Marquette. Wiley does not grant permission for this article to be further copied/distributed or hosted elsewhere without the express permission from Wiley. 
NOT THE PUBLISHED VERSION; this is the author's final, peer-reviewed manuscript. The published version may be accessed by following the link in the citation at the bottom of the page.

Table 1. Intercorrelations for Triangulation and Appraisals at Both Time Points

\begin{tabular}{|c|c|c|c|c|c|c|c|c|c|c|c|}
\hline Variables & 1 & 2 & 3 & 4 & 5 & 6 & 7 & 8 & 9 & 10 & 11 \\
\hline \multicolumn{12}{|c|}{ 1. IP conflict T1 - } \\
\hline 2. Triang. T1 & $.49^{* *}$ & - & & & & & & & & & \\
\hline 3. Threat T1 & $.45^{* *}$ & $.40^{* *}$ & - & & & & & & & & \\
\hline 4. Coping $\mathrm{T} 1$ & $-.43^{* *}$ & $-.12^{*}$ & $-.47^{* *}$ & - & & & & & & & \\
\hline 5. Blame T1 & $.21^{* *}$ & $.41^{* *}$ & $.27^{* *}$ & -.10 & - & & & & & & \\
\hline 6. Triang. T2 & $.46^{* *}$ & $.67^{* *}$ & $.44^{* *}$ & $-.24^{* *}$ & $.35^{* *}$ & - & & & & & \\
\hline 7. Threat T2 & $.33^{* *}$ & $.27^{* *}$ & $.73^{* *}$ & $-.46^{* *}$ & $.24^{* *}$ & $.50^{* *}$ & - & & & & \\
\hline 8. Coping T2 & $-.36^{* *}$ & $-.17 *$ & $-.44^{* *}$ & $-.60^{* *}$ & ${ }^{*}-.11$ & $-.31^{* *}$ & $-.56^{* *}$ & ${ }^{*}-$ & & & \\
\hline 9. Blame T2 & $.19^{*}$ & $.35^{* *}$ & $.29^{* *}$ & -.11 & $.70^{* *}$ & $.53^{* *}$ & $.41^{* *}$ & $-.25^{* *}$ & * & & \\
\hline 10. Age & -.05 & -.06 & $-.16^{*}$ & -.01 & -.11 & $-.17^{*}$ & $-.21^{*}$ & .06 & $-.28^{* *}$ & ${ }^{*}-$ & \\
\hline 11. Divorce & $.24^{* *}$ & $.15^{*}$ & .02 & .06 & .06 & .12 & -.12 & .02 & .09 & .04 & - \\
\hline 12. Gender & -.07 & .04 & -.11 & $-.18^{* *}$ & k. & -.16 & -.11 & $-.21^{*}$ & .02 & .03 & -.01 \\
\hline M & 18.11 & 5.36 & 3.48 & 6.30 & 3.68 & 5.37 & 3.39 & 6.53 & 4.15 & 16.32 & 1.47 \\
\hline$S D$ & 9.90 & 3.53 & 3.19 & 2.42 & 3.83 & 3.82 & 3.22 & 2.23 & 3.77 & 1.17 & .50 \\
\hline
\end{tabular}

Note: $N=2$,948. IP Conflict $=$ interparental conflict. Gender is scored girls $=1$ and boys $=2$.

${ }^{*} p<.05$

${ }^{* *} p<.01$.

Then, a two-wave, cross-lagged path model was computed to evaluate whether triangulation predicted increases or decreases in adolescent threat, blame, and coping efficacy over time and whether these appraisals predicted increases or decreases in adolescent triangulation by T2 after accounting for interparental conflict at T1. Model group comparisons were tested by constraining path coefficients to be the same for boys and girls. The constrained model provided a good fit with the data, $X^{2}(56)=79.109, p<.05$, CFI $=.97$, TLI $=.93$, RMSEA $=.04$, indicating that models did not differ for boys and girls. This procedure was repeated to evaluate whether models were consistent for children who had and had not experienced divorce. This

Journal of Marriage and the Family, Vol 72, No. 2 (Summer 2010): pg. 254-266. DOI. This article is (c) Wiley and permission has been granted for this version to appear in e-Publications@Marquette. Wiley does not grant permission for this article to be further copied/distributed or hosted elsewhere without the express permission from Wiley. 
second constrained model also fit well with the data, $X^{2}(46)=76.313$, $p<.01$, CFI $=.96$, TLI $=.89$, RMSEA $=.05$, which indicated that models did not differ as a function of experiencing divorce. Thus, the model was computed with the whole sample, with gender, age, and divorce added as covariates, and provided a good fit with the data, $X^{2}(18)=30.59, p=.03$, CFI $=.98$, TLI $=.93$, RMSEA $=.05$.

Statistically nonsignificant paths were dropped from the model, and T1 divorce status was also dropped from the model because it was not associated with any endogenous variables. The final model retained good fit with the data, $X^{2}(26)=34.11, p=.13$, CFI $=.99$, TLI $=.97$, RMSEA $=.031$, and is presented in Figure 1.

Figure 1. Longitudinal Model of Interparental Conflict, Triangulation, and Appraisals.

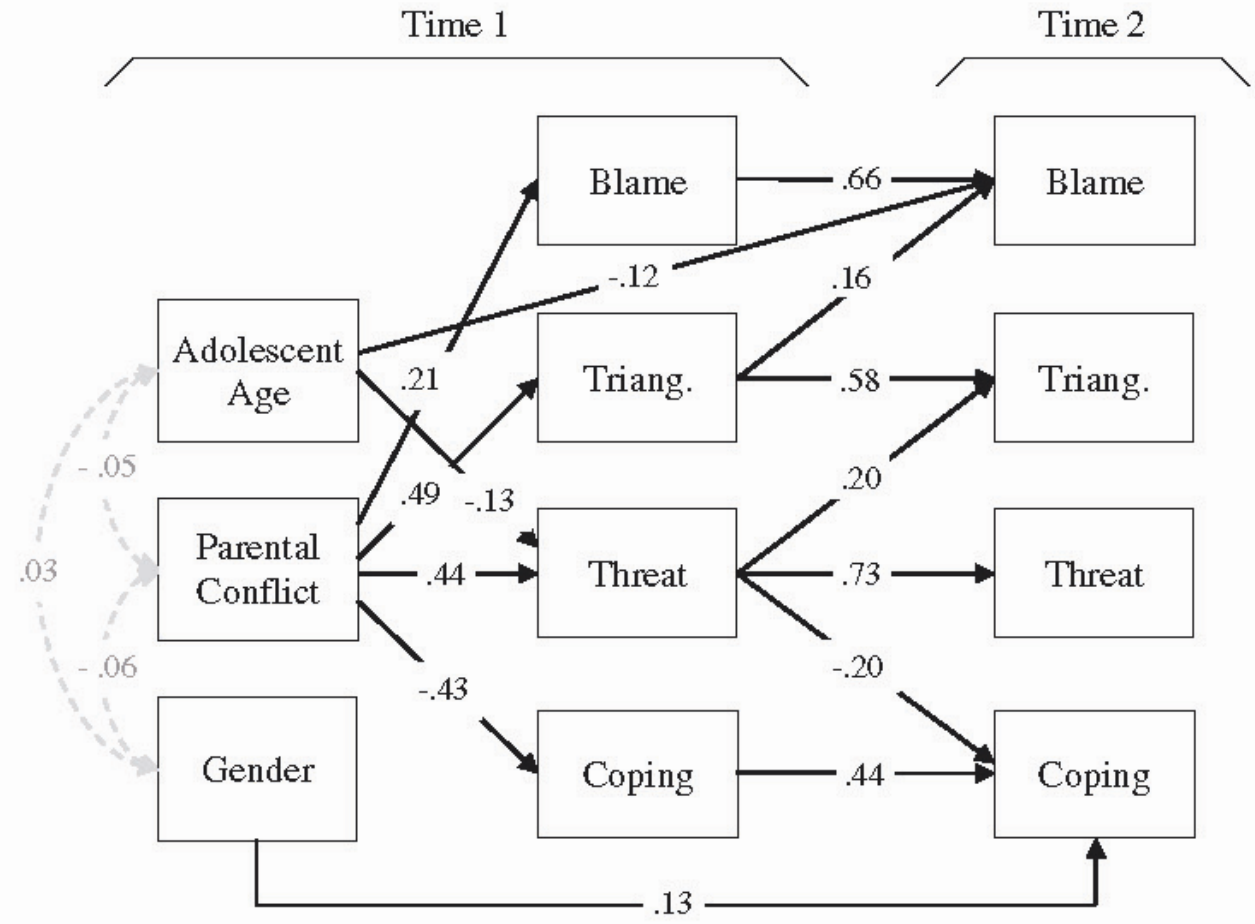

Note: $\chi^{2}(26)=34.11, p=.13$, CFI $=.99$, TLI $=.97$, RMSEA $=.031(90 \% .00-.057)$. All paths are significant at $p<.05$. Correlations $(\mathrm{T} 1 / \mathrm{T} 2)$ : Bla-Tri. $=.36^{* *} / .43^{* *}$; BlaTh. $=.19^{* *} / .43^{* *}$; Bla- Cop $=.00 / .15 ;$ Tri-Th. $=.24^{* *} / .50^{* *}$; Tri-Cop. $=.10 /-.26^{* *}$; Cop-Th. $=.35^{* *} / .41 .^{* *}$

Journal of Marriage and the Family, Vol 72, No. 2 (Summer 2010): pg. 254-266. DOI. This article is (C) Wiley and permission has been granted for this version to appear in e-Publications@Marquette. Wiley does not grant permission for this article to be further copied/distributed or hosted elsewhere without the express permission from Wiley. 
NOT THE PUBLISHED VERSION; this is the author's final, peer-reviewed manuscript. The published version may be accessed by following the link in the citation at the bottom of the page.

After accounting for participants' age and gender, adolescents who reported exposure to more intense, frequent, and poorly resolved interparental conflict also reported greater levels of triangulation ( $\beta$ $=.49)$, threat $(\beta=.44)$, and self-blame $(\beta=.21)$ and reported feeling less able to cope $(\beta=-.43)$ at $\mathrm{T} 1$, and each of these processes were stable over the 6-month period between assessments ( $\beta$ s: .44 to .73). Autoregressive paths showed that interparental conflict at T1 did not predict later levels of triangulation and appraisals; triangulation and appraisals were linked over time, however. Specifically, adolescent triangulation at T1 was associated with increases in self-blame appraisals over time $(\beta=.16)$ but was not associated with T2 threat or coping efficacy. Perceiving parental conflict as threatening at T1 was associated with increases in adolescent triangulation $(\beta=.20)$ and decreases in adolescents' coping efficacy $(\beta=-.20) 6$ months later. In addition, adolescent age was associated with self-blame, which indicated that older adolescents reported less self-blame over time ( $\beta$ $=-.12)$. Also, gender was associated with coping and indicated that boys reported greater coping over time $(\beta=.13)$.

\section{Triangulation and Parent-Child Relations}

The second set of analyses focused on the impact of triangulation for parent-adolescent relations and included both parentadolescent conflict and closeness in the models. Table 2 presents means, standard deviations, and correlations. As shown, interparental conflict, triangulation, and parent-child relations all were correlated. Constructs all were stable over time, with correlations ranging from .56 to .85 ( $p s<.01)$. Adolescents who were exposed to greater levels of interparental conflict at $\mathrm{T} 1$ reported less closeness with their mothers and fathers and greater conflict with mothers and fathers at T2. Similarly, adolescents who reported feeling triangulated into parental conflicts at T1 also felt less close with mothers at T2 and with fathers at T1 and T2. Triangulation also was associated with greater conflict with mothers and fathers at both time points. T1 closeness and conflict with parents were not significantly correlated with T2 triangulation. Finally, conflict with parents and closeness were inversely related at both time points for mothers and fathers.

Journal of Marriage and the Family, Vol 72, No. 2 (Summer 2010): pg. 254-266. DOI. This article is (c) Wiley and permission has been granted for this version to appear in e-Publications@Marquette. Wiley does not grant permission for this article to be further copied/distributed or hosted elsewhere without the express permission from Wiley. 
NOT THE PUBLISHED VERSION; this is the author's final, peer-reviewed manuscript. The published version may be accessed by following the link in the citation at the bottom of the page.

Table 2. Intercorrelations for Triangulation and Parent-Adolescent Relations at Both Time Points

\begin{tabular}{|c|c|c|c|c|c|c|c|c|c|c|c|c|c|}
\hline Variables & 1 & 2 & 3 & 4 & 5 & 6 & 7 & 8 & 9 & 10 & 11 & 12 & 13 \\
\hline 1. IP conflict $\mathrm{T} 1$ & - & & & & & & & & & & & & \\
\hline 2. Triang. T1 & $49^{* *}$ & - & & & & & & & & & & & \\
\hline 3. Mom con. $\mathrm{T} 1$ & $.36^{* *}$ & $.25^{*}$ & - & & & & & & & & & & \\
\hline 4. Mom close $\mathrm{T} 1$ & $-.33^{* *}$ & -.07 & $-.49^{* *}$ & - & & & & & & & & & \\
\hline 5. Dad con. T1 & $.45^{* *}$ & $.28^{* *}$ & $.40^{* *}$ & $-.26^{* *}$ & - & & & & & & & & \\
\hline 6. Dad close $\mathrm{T} 1$ & $-.32^{* *}$ & $-.17^{* *}$ & .09 & $.33^{* *}$ & $-.45^{* *}$ & - & & & & & & & \\
\hline 7. Triang. T2 & $46^{* *}$ & $.67^{* *}$ & .11 & -.13 & .13 & -.13 & - & & & & & & \\
\hline 8. Mom con. T2 & $36^{* *}$ & $.31^{* *}$ & $.61^{* *}$ & $-.43^{* *}$ & .19 & .13 & $39 * *$ & - & & & & & \\
\hline 9. Mom close $\mathrm{T} 2$ & $-.36^{* *}$ & $-.19^{* *}$ & $-.54^{* *}$ & $.85^{* *}$ & $-.26^{* *}$ & $.26^{* *}$ & $-.23^{* *}$ & $-.51^{* *}$ & - & & & & \\
\hline 10. Dad con. T2 & $.43^{* *}$ & $.44^{* *}$ & .11 & -.12 & $.56^{* *}$ & $-.25^{* *}$ & $.39^{* *}$ & $.43^{* *}$ & -.19 & - & & & \\
\hline 11. Dad close T2 & $-39^{* *}$ & $-.29^{* *}$ & -.05 & $.18^{* *}$ & $-.54^{* *}$ & $.81^{* *}$ & $-.23^{* *}$ & .03 & $.23^{* *}$ & $-34^{* *}$ & - & & \\
\hline 12. Child age & -.05 & -.06 & .03 & $-.14 *$ & .03 & -.08 & $-.17 *$ & .01 & -.02 & -.10 & .01 & - & \\
\hline 13. Divorce & $.24^{* *}$ & $.14^{*}$ & $19^{* *}$ & -.06 & .03 & -.10 & .12 & -.06 & $.23 *$ & -.08 & .13 & .04 & - \\
\hline 14. Gender & -.07 & .04 & $-.17^{* *}$ & $.16^{* *}$ & -.02 & .01 & -.16 & -.09 & .10 & .10 & .01 & .03 & -.01 \\
\hline M & 18.11 & 5.35 & 55.94 & 70.42 & 46.92 & 62.75 & 5.27 & 51.91 & 67.16 & 43.88 & 65.24 & 16.32 & 1.47 \\
\hline$S D$ & 9.90 & 3.53 & 65.61 & 18.76 & 57.68 & 19.82 & 3.92 & 52.56 & 18.87 & 51.57 & 18.75 & 1.17 & .50 \\
\hline
\end{tabular}

Note: $\mathrm{N}=3,279$. IP conflict $=$ interparental conflict; $\mathrm{mom} /$ dad close $=$ closeness with mothers or fathers.

$* p<.05 ; * * p<.01$.

Initially, separate path models were computed for adolescent relations with mothers and fathers, following the same analytic plan. Cross-lagged panel designs were used to evaluate the degree to which interparental conflict and triangulation predicted changes in parentadolescent relationship quality and conflict over time and the degree to which parent-adolescent relations predicted changes in triangulation. For mothers and fathers, the patterns of results were similar. Gender group comparisons models constraining paths to be the same across models indicated good fit and suggested that models did not significantly differ for boys and girls: father model: $X^{2}(37)=58.199, p$ $=.02$, TLI $=.89, \mathrm{CFI}=.96$, RMSEA $=.04$; mother model: $\chi^{2}(34)=$ $51.10, p=.03, \mathrm{TLI}=.92, \mathrm{CFI}=.97, \mathrm{RMSEA}=.04$. This procedure was repeated to evaluate whether models differed on the basis of exposure to divorce and this indicated that models did not differ systematically: father model: $X^{2}(26)=42.29, p=.02$, TLI $=.90$, CFI $=.96, \mathrm{RMSEA}=.04$; mother model: $\chi^{2}(34)=43.53, p=.13$, TLI $=.96, \mathrm{CFI}=.98, \mathrm{RMSEA}=.03$. Models were then computed with the full sample and provided a good fit with the data for the fatheradolescent, $X^{2}(10)=7.635, p=.66$, TLI $=1.02$, CFI $=1.00$; RMSEA $=.00$, and mother-adolescent models, $X^{2}(12)=17.41, p=.14$, TLI $=.96, \mathrm{CFI}=.99$, RMSEA $=.04$. Child gender was not correlated with any father-adolescent variables and was not included in that model. Divorce was initially included in the models, but because it was not associated with any endogenous variables it was dropped in both models. Nonsignificant paths were trimmed, and the resulting models 
yielded identical patterns of results among the variables except that child gender was linked with mother-child relations at T1 and youth age was associated with T1 closeness with mothers but not fathers.

Because of the similar pattern of results among constructs of interest for the two models and the lack of group differences within models, a combined model was computed. First, mother and father variables were combined by averaging $z$-scored values to create two relationship composite variables: parent-adolescent conflict and parent-adolescent closeness. Then, all significant paths from motheradolescent and father-adolescent models were included in the combined model, $X^{2}(13)=12.11, p=.52$, TLI $=1.00, \mathrm{CFI}=1.00$, RMSEA $=.00$. Adolescent gender was not associated with T1 parentadolescent conflict or closeness as found in the mother-adolescent model and was dropped from the model. The final model retained good fit with the data, $X^{2}(9)=3.51, p=.94$, TLI $=1.04, \mathrm{CFI}=1.00$, RMSEA $=.00$. As shown in Figure 2, interparental conflict was associated with $\mathrm{T} 1$ triangulation $(\beta=.49)$, less close parentadolescent relationships $(\beta=-.39)$, and more parent-adolescent conflict $(\beta=.45)$. Also, youth age was associated with less closeness at T1 $(\beta=-.14)$ and less triangulation at T2 $(\beta=-.16)$. Cross-lagged associations revealed that T1 parental conflict was associated with greater triangulation at T2 $(\beta=.13, p<.07)$ after accounting for T1 triangulation $(\beta=.58)$. Triangulation at $\mathrm{T} 1$ was associated with less closeness with parents $(\beta=-.15)$, and greater parent-adolescent conflict ( $\beta=.27$ ) at T2, accounting for previous levels. Also consistent with mother and father models, parent-adolescent conflict at T1 was associated with less close relationships $(\beta=-.18)$ over time. 
Figure 2. Triangulation and Parent-Adolescent Relations.

Time 1

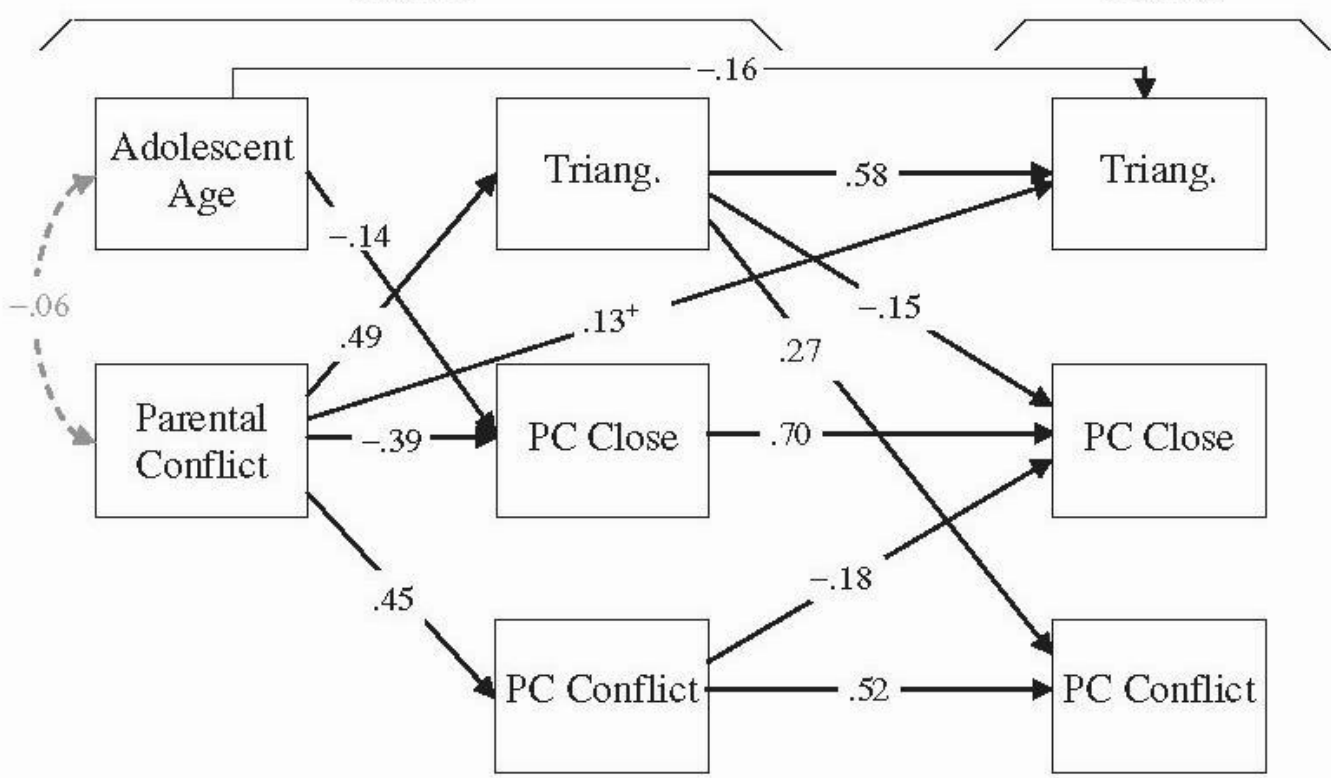

Note: $X^{2}(9)=3.51, p=.94, \mathrm{TLI}=1.04, \mathrm{CFI}=1.00, \mathrm{RMSEA}=.000$. All paths are significant at $p<.01$, unless marked ${ }^{+} p<.07$. Correlations $(\mathrm{T} 1 / \mathrm{T} 2)$ : Close-Tri $=.07 /-.26^{* *}$; Con-Close $=-.34^{* *} /-.15$; Triang.- Con.$=.10 / .31 .^{* *}$

\section{Discussion}

This study highlights the importance of incorporating family systems dynamics, specifically triangulation, when evaluating the impact of interparental conflict on adolescent appraisals and parentadolescent relations. Consistent with past research, adolescents reported the highest levels of triangulation in families with intense, frequent, and poorly resolved interparental conflict (Grych et al., 2004; Minuchin, 1974). Feeling caught in the middle of parental disagreements consistently predicted greater self-blame and poorer parent-adolescent relations; moreover, the longitudinal design of the study enabled us to examine the temporal nature of these associations. The pattern of results, which was consistent for boys and girls and for intact and divorced families, is discussed below. 


\section{Triangulation and Appraisals: Examining Bidirectional Effects}

By collecting data at two points in time, 6 months apart, this study provides new information about the direction of relationships between triangulation and adolescent self-blaming and threat appraisals. Our findings suggest that self-blame follows, rather than precedes, feeling caught in the middle of parental conflicts. When adolescents felt drawn into parental disagreements, the belief that they were responsible for causing or resolving parental conflicts increased over time. This is consistent with the family systems view that overly permeable boundaries between interparental and parentchild subsystems may lead adolescents to accept responsibility for the executive functioning of the family, which is developmentally inappropriate and ultimately linked with poorer adjustment (Kerig, 2005). Interestingly, self-blame at T1 did not predict adolescents' experience of triangulation over time, suggesting that this belief does not lead them to feel caught in the middle of parental conflicts but rather is the product of triangulation. This differs from Grych and Fincham's (1993) finding that preadolescents indicated they were more likely to intervene in parental disagreements on child-related topics. It may be that children become involved in such conflicts not because they blame themselves for causing them but because they want to represent their point of view or to play a role in determining the outcome of the discussion. Another possibility is that there may be developmental differences between preadolescents and adolescents surveyed by Grych and Fincham (1993) and the current study. Research that directly examines children's motivations for intervening in conflict is needed to better understand whether (or when) their appraisals can lead to triangulation.

In contrast to the findings regarding self-blame, perceiving parental conflict as more threatening predicted increases in adolescent triangulation. This is consistent with the cognitive-contextual and emotional security models, in which threat is postulated to guide coping responses (Davies \& Cummings, 1998; Grych \& Fincham, 1990). The current findings suggest that adolescents may involve themselves in parental conflicts in an effort to cope with fears elicited by interparental discord. Interestingly, adolescents' coping efficacy

Journal of Marriage and the Family, Vol 72, No. 2 (Summer 2010): pg. 254-266. DOI. This article is (c) Wiley and permission has been granted for this version to appear in e-Publications@Marquette. Wiley does not grant permission for this article to be further copied/distributed or hosted elsewhere without the express permission from Wiley. 
beliefs and triangulation were not linked over time, which suggests that adolescents' involvement in parental conflicts and their ability to make themselves feel better are distinct processes. Finally, threat appraisals predicted diminished coping efficacy over time, extending previous cross-sectional findings linking threat and coping appraisals (Gerard et al., 2005; Grych \& Fincham, 1993).

Taken together, these findings may help explain divergent pathways by which threat is linked with internalizing and externalizing problems (Rhoades, 2008). Threat may be linked with internalizing patterns of adjustment when these appraisals undermine youths' ability to cope effectively with their distress about interparental conflict. When threat appraisals motivate adolescents to become involved in parental conflicts, they are exposed to and may engage in more hostile and aggressive interactions with their parents, effectively socializing aggression and externalizing problems (Davis et al., 1998; Fosco \& Grych, 2008).

\section{Triangulation and Parent-Adolescent Relations}

The second goal of this study was to examine triangulation as a mechanism through which conflict in the interparental relationship may spill over into parent-adolescent relations. The weakening of interparental boundaries may undermine an important parentadolescent hierarchy by placing adolescents in a position of power beyond what is developmentally appropriate (Minuchin, 1974). This boundary ambiguity may lead to confusion about adolescents' roles in the family or the importance of respecting parental authority.

The current findings suggest that triangulation is disruptive to parent-adolescent relations, and the pattern of results were the same for mother- and father-adolescent relations. Adolescents who reported feeling triangulated at T1 evidenced increases in the levels of conflict with their parents over time. This is consistent with other research demonstrating that involvement in parental disagreements increases adolescents' argumentative responses during parental conflicts (Davis et al., 1998) and that covert conflict was associated with more global parent-adolescent conflict (Bradford et al., 2008). If children take sides in a disagreement, they may experience increased conflict with the parent they oppose even after the conflict ends. The present study 
focused on parent-adolescent conflict beyond the context of interparental arguments and highlights triangulation as a mechanism through which hostility and conflict in the interparental subsystem may be transmitted into the parent-adolescent subsystems. It should be noted, however, that the measure of parent-adolescent conflict captured parents' conflict behaviors rather than measuring aspects of dyadic interactions.

Moreover, this study also found a link between triangulation and deterioration to the quality of parent-adolescent relationships, even with parent-adolescent conflict accounted for in the model. This suggests that involvement in parental conflicts directly undermines adolescents' feelings of trust and security with their parents, independent of the level of conflict in the parent-adolescent relationships. It is possible that triangulation, which is often distressing for adolescents, contradicts the positive view of their parents as dependable sources of support or leads them to withdraw in their relationships with their parents (Buchanan \& Waizenhofer, 2001). Youths who are often caught in the middle of parental conflicts also may build up resentment toward one or both parents for putting them in a difficult and stressful position.

In sum, the results of this study provide compelling support for the importance of maintaining clear interparental (executive) subsystem boundaries. The violation of these boundaries through triangulation is linked with the deterioration of adolescent-parent relations, through increased conflict and reduced closeness with parents, which can place adolescents at risk for psychological maladjustment (Buehler \& Gerard, 2001) and susceptibility to deviant peer influences (Dishion, Nelson, \& Bullock, 2004).

\section{Limitations and Future Directions}

The present investigation found diverse implications for triangulation into parental conflicts; however, the measurement of triangulation captured adolescent's subjective feelings of being caught in the middle and does not allow for evaluation of the specific aspects of triangulation that are linked with self-blame, threat, or parentadolescent relations. It is not clear whether adolescent perceptions of triangulation followed from being drawn into the conflict or trying to 
intervene, or if they occurred without the adolescent actually becoming involved. Examining the different ways that youths become triangulated will further illuminate links with their appraisals and parent-child relationships. For example, it may be that threat is associated with adolescent-initiated triangulation, and parent-initiated triangulation is more likely to lead to self-blame. Further, it is possible that different forms of triangulation are linked with parent-adolescent relations, such as scapegoating and parent-adolescent conflict and cross-generational coalitions and parent-adolescent closeness.

Although there are advantages to focusing on adolescents' subjective evaluations of conflict, triangulation, and appraisals because they provide important information about their experiences in the family (Grych \& Fincham, 1990), the reliance on adolescent self-report data in this study also is a methodological limitation. Concerns that the associations are inflated because of monomethod variance are reduced by the use of structural equation modeling techniques that account for shared variance at each time point, but this approach does not fully eliminate the problem. Moreover, using adolescents as the sole reporters cannot offer a complete picture of family functioning. It would be valuable to identify whether these patterns of results are replicated when observational and parent-report data are utilized, to better understand ways of assessing family functioning and to evaluate how robust these associations are.

In addition, the measure of adolescent coping efficacy did not yield optimal values for internal consistency. This increases the expected error variance measured by this scale and reduces the probability of having a statistically significant relationship with other variables in the model. Despite these limitations, threat was linked with coping efficacy, consistent with past research (Grych et al., 1992), but relationships with other factors may be underrepresented. Until these findings can be replicated, cautious interpretation is warranted.

Finally, attrition in this sample is an important limitation. In this study, we used full information maximum likelihood estimation techniques, which avoids biasing analyses due to missing data. And, although there were no systematic patterns of missing data among the

Journal of Marriage and the Family, Vol 72, No. 2 (Summer 2010): pg. 254-266. DOI. This article is (C) Wiley and permission has been granted for this version to appear in e-Publications@Marquette. Wiley does not grant permission for this article to be further copied/distributed or hosted elsewhere without the express permission from Wiley. 
NOT THE PUBLISHED VERSION; this is the author's final, peer-reviewed manuscript. The published version may be accessed by following the link in the citation at the bottom of the page.

constructs of interest, youths who were older at T1 and who reported coming from divorced households were less likely to participate at T2.

\section{Conclusions}

Consistent with family systems theory, this study shows that when interparental conflict is persistent, hostile, and unresolved, adolescents are more likely to be drawn into the arguments. Triangulation is more likely to occur when youths feel threatened by conflict and, in turn, may lead adolescents to blame themselves for parental conflicts or feel responsible for solving their parents' problems. Youths' sense of being caught in the middle of parental disagreements was consistently detrimental to parent-adolescent relations, both with mothers and fathers, resulting in greater conflict and diminished closeness in their relationships. These data further suggest that triangulation is not the result of exceptionally close adolescent-parent relationships but, rather, is a product of dysregulated and poorly managed interparental conflict. From an applied perspective, these data highlight the importance of careful assessment of the links between individual, dyadic, and triadic functioning in families characterized by high levels of discord and indicate that intervention efforts with these families should aim to strengthen the interparental subsystem boundary in order to foster healthy adolescent development.

\section{Note}

Portions of these findings were previously presented at the Society for Research on Adolescence 2006 biennial conference. The authors would like to thank the participants and staff at Hamilton High School in Milwaukee, Wisconsin, for their participation in this study. We also would like to thank graduate and undergraduate research assistants who aided in the collection and preparation of these data.

\section{References}

Arbuckle, J. L. (2007). Amos 16.0 [Computer software]. Chicago: SPSS.

Armsden, G. C., \& Greenberg, M. T. (1987). The Inventory of Parent and Peer Attachment: Individual differences and their

Journal of Marriage and the Family, Vol 72, No. 2 (Summer 2010): pg. 254-266. DOI. This article is (c) Wiley and permission has been granted for this version to appear in e-Publications@Marquette. Wiley does not grant permission for this article to be further copied/distributed or hosted elsewhere without the express permission from Wiley. 
relationship to psychological wellbeing in adolescence. Journal of Youth and Adolescence, 16, 427-454.

Bickham, N. L., \& Fiese, B. H. (1997). Extension of the Children's Perceptions of Interparental Conflict Scale for use with late adolescents. Journal of Family Psychology, 11, 246-250.

Bradford, K., Vaughn, L. B., \& Barber, B. K. (2008). When there is conflict: Interparental conflict, parent-child conflict, and youth problem behaviors. Journal of Family Issues , 29, 780-805.

Bosco, G. L., Renk, K., Dinger, T. M., Epstein, M. K., \& Phares, V. (2003). The connections between adolescents' perceptions of parents, parental psychological symptoms, and adolescent functioning. Applied Developmental Psychology, 24, 179-200.

Buchanan, C. M., Maccoby, E. E., \& Dornbusch, S. M. (1991). Caught between parents: Adolescents' experience in divorced homes. Child Development, 62, 1008-1029.

Buchanan, C. M., \& Waizenhofer, R. (2001). The impact of interparental conflict on adolescent children: Considerations of family systems and family structure. In A.Booth, A. C.Crouter, \& M.Clements (Eds.), Couples in conflict (pp. 149-160). Mahwah, NJ: Erlbaum.

Buehler, C., \& Gerard, J. M. (2001). Marital conflict, ineffective parenting, and children's and adolescents maladjustment. Journal of Marriage and Family, 64, 78-92.

Buehler, C., Lange, G., \& Franck, K. L. (2007). Adolescents' cognitive and emotional responses to marital hostility. Child Development, 78, 775-789.

Crawford, L. A., \& Novak, K. B. (2008). Parent-child relations and peer associations as mediators of the family structure-substance use relationship. Journal of Family Issues, 29, 155-184.

Davies, P. T., \& Cummings, E. M. (1994). Marital conflict and child adjustment: An emotional security hypothesis. Psychological Bulletin, 116, 387-411.

Davies, P. T., \& Cummings, E. M. (1998). Exploring children's emotional security as a mediator of the link between marital relations and child adjustment. Child Development, 69, 124139.

Davies, P. T., \& Forman, E. M. (2002). Children's patterns of preserving emotional security in the interparental subsystem. Child Development, 73, 1880-1903.

Journal of Marriage and the Family, Vol 72, No. 2 (Summer 2010): pg. 254-266. DOI. This article is (C Wiley and permission has been granted for this version to appear in e-Publications@Marquette. Wiley does not grant permission for this article to be further copied/distributed or hosted elsewhere without the express permission from Wiley. 
Davies, P. T., Harold, G. T., Goeke-Morey, M., \& Cummings, E. M. (2002). Child emotional security and interparental conflict. Monographs of the Society for Research in Child Development, 67 (3, Serial No. 270).

Davis, B. T., Hops, H., Albert, A., \& Sheeber, L. (1998). Child responses to parental conflict and their effect on adjustment: A study of triadic relations. Journal of Family Psychology, 12, 163177.

Dishion, T. J., Nelson, S. E., \& Bullock, B. M. (2004). Premature adolescent autonomy: Parent disengagement and deviant peer process in the amplification of problem behaviour. Journal of Adolescence, 27, 515-530.

El-Sheikh, M., \& Elmore- Staton, L. (2004). The link between marital conflict and child adjustment: Parent-child conflict and perceived attachments as mediators, potentiators, and mitigators of risk. Development and Psychopathology , 16, 631-648.

Erel, O., \& Burman, B. (1995). Interrelatedness of marital relations and parent-child relations: A meta-analytic review. Psychological Bulletin, 118, 108-132.

Fosco, G. M., \& Grych, J. H. (2008). Emotional, cognitive, and family systems mediators of children's adjustment to interparental conflict. Journal of Family Psychology, 22, 843-854.

Gerard, J. M., Buehler, C., Franck, K., \& Anderson, O. (2005). In the eyes of the beholder: Cognitive appraisals as mediators of the association between interparental conflict and youth maladjustment. Journal of Family Psychology, 19, 376-384.

Grych, J. H., \& Fincham, F. D. (1990). Marital conflict and children's adjustment: A cognitive-contextual framework. Psychological Bulletin, 108, 267-290.

Grych, J. H., \& Fincham, F. D. (1993). Children's appraisals of marital conflict: Initial investigations of the cognitive-contextual framework. Child Development, 64, 215-230.

Grych, J. H., Raynor, S. R., \& Fosco, G. M. (2004). Family processes that shape the impact of interparental conflict on adolescents. Development and Psychopathology, 16, 649-665.

Grych, J. H., Seid, M., \& Fincham, F. D. (1992). Assessing marital conflict from the child's perspective: The Children's Perception of Interparental Conflict Scale. Child Development, 63, 558-572.

Journal of Marriage and the Family, Vol 72, No. 2 (Summer 2010): pg. 254-266. DOI. This article is (C Wiley and permission has been granted for this version to appear in e-Publications@Marquette. Wiley does not grant permission for this article to be further copied/distributed or hosted elsewhere without the express permission from Wiley. 
Jouriles, E. N., Spiller, L. C., Stephens, N., McDonald, R., \& Swank, P. (2000). Variability in adjustment of children of battered women: The role of child appraisals of interparent conflict. Cognitive Therapy and Research, 24, 233-249.

Kerig, P. K. (1995). Triangles in the family circle: Effects of family structure on marriage, parenting and child adjustment. Journal of Family Psychology, 9, 28-43.

Kerig, P. K. (2005). Revisiting the construct of boundary dissolution: A multidimensional perspective. Journal of Emotional Abuse, 5, 542.

Krishnakumar, A., \& Buehler, C. (2000). Interparental conflict and parenting behaviors: A meta-analytic review. Family Relations, $49,25-44$.

Lindahl, K. M. (1998, November). Triadic family observational coding: The use of a global coding system with a multi-ethnic sample. Paper presented at the Annual Convention of the Association for Advancement of Behavior Therapy, Washington, DC.

Minuchin, S. (1974). Families and family therapy. Cambridge, MA: Harvard University Press.

Peris, T. S., Goeke-Morey, M. C., Cummings, E. M., \& Emery, R. E. (2008). Marital conflict and support seeking by parents in adolescence: Empirical support for the parentificaton construct. Journal of Family Psychology, 22, 633-642.

Rhoades, K. A. (2008). Children's responses to interparental conflict: A meta-analysis of their associations with adjustment. Child Development, 6, 1942-1956.

Schermerhorn, A. C., Cummings, E. M., DeCarlo, C. A., \& Davies, P. T. (2007). Children's influence in the marital relationship. Journal of Family Psychology, 21, 259-269.

Shelton, K. H., Harold, G. T., Goeke-Morey, M. C., \& Cummings, E. M. (2006). Children's coping with marital conflict: The role of conflict expression and gender. Social Development, 15, 232247.

Straus, M. A. (1979). Measuring intrafamily conflict and violence: The Conflict Tactics (CT) scales. Journal of Marriage and the Family, 41, 75-88.

Widaman, K. F. (2006). Missing data: What to do with or without them. Monographs of the Society for Research in Child Development, 71(3), 42-64.

Journal of Marriage and the Family, Vol 72, No. 2 (Summer 2010): pg. 254-266. DOI. This article is (c) Wiley and permission has been granted for this version to appear in e-Publications@Marquette. Wiley does not grant permission for this article to be further copied/distributed or hosted elsewhere without the express permission from Wiley. 